\title{
Pleural fluid ferritin concentrations in human disease
}

\author{
MATTI KLOCKARS, $\S$ TEDDY WEBER, $\dagger$ PIRJO TANNER, $\dagger$ \\ PÄHR-EINAR HELLSTRÖM, $\ddagger$ TOM PETTERSSON* \\ From the * Fourth Department of Medicine, Helsinki University Central Hospital, Helsinki, Finland, the \\ $†$ Minerva Institute for Medical Research, and Medix Laboratories Ltd, Helsinki, $¥$ Mjölbolsta Hospital, \\ Finland, and the §Institute of Occupational Health, Helsinki, Finland
}

SUMmary The concentration of ferritin was measured in the pleural fluid of 108 patients with pleural effusions. In all groups of patients the ferritin concentration was higher in pleural fluid than in serum. The greatest differences, with up to 100 times more ferritin in the pleural fluid, were found for patients with rheumatoid pleurisy, malignant effusions, and empyema. In patients with non-malignant inflammatory pleural effusions the concentration of ferritin in pleural fluid correlated significantly with other pleural fluid indices of inflammation: there was a positive correlation with lactate dehydrogenase activity and a negative correlation with concentrations of glucose and complement components $\mathrm{C} 3$ and $\mathrm{C} 4$. Ferritin was detected immunocytochemically only in the macrophages found among the pleural fluid cells.

Our study shows that large amounts of ferritin accumulate locally in the pleural cavity in certain types of pleural inflammation. The accumulation is probably partly the result of increased local reticuloendothelial system activity. Determination of the concentration of ferritin in pleural fluid may provide corroborative information for differential diagnosis and may further our understanding of the pathogenetic events that lead to the perpetuation of inflammatory activity in pleural effusions.

Ferritin, an iron storage protein with a molecular weight of about 450000 , in apoferritin form, is found mainly in the liver and in cells of the reticuloendothelial (mononuclear phagocyte) system. In healthy adults the concentration of ferritin in serum is positively correlated with the iron stores in the body.'

Determination of serum ferritin is useful in the diagnosis of iron deficiency anaemia and iron overload-for example, haemochromatosis. Increased serum concentrations of ferritin have been found in patients with severe liver disease-for example, patients with alcoholic liver disease, ${ }^{2}$ and viral or drug induced hepatic necrosis. ${ }^{3}$ High concentrations of serum ferritin have also been reported for patients with malignancies, particularly those with cancer of the breast, lung, pancreas, or liver, but also for some patients with leukaemia and Hodgkin's disease. ${ }^{14}$ In the inflammatory response ferritin possibly behaves as an acute phase protein $^{5-7}$; in rheumatoid arthritis, concentrations of ferritin in synovial fluid have been found to be increased when compared with serum values. ${ }^{8}$

Accepted for publication 5 February 1985
This study was undertaken to determine the diagnostic value of measuring the concentration of ferritin in the serum and pleural fluid of patients with pleural effusions caused by different diseases. Biochemical and immunological measurements of inflammatory activity in the pleural cavity were correlated with the results of ferritin assays in order to elucidate the pathogenetic events of pleural effusions.

\section{Patients and methods}

One hundred and eight patients with pleural effusion were studied. Paired samples of serum and pleural fluid were collected from 70 patients, and for the remainder only pleural fluid was studied. The cause of the pleural effusion was determined for each patient from clinical, laboratory, and radiological findings. The patients were divided into groups on the basis of their final diagnosis (Table 1).

Total and differential leucocyte counts, erythrocyte counts, lactate dehydrogenase activity, and concentrations of total protein, glucose, and complement components $\mathrm{C} 3$ and $\mathrm{C} 4$ were determined as described previously. ${ }^{9}$ 
Table 1 Groups of patients studied

\begin{tabular}{|c|c|c|c|}
\hline No of patients & Sex ratio $(M: F)$ & Age (yr) Mean (range) & Diagnosis \\
\hline $\begin{array}{r}5 \\
5 \\
12 \\
9 \\
3 \\
51\end{array}$ & $\begin{array}{c}5: 0 \\
5: 0 \\
10: 2 \\
8: 1 \\
2: 1 \\
29: 22\end{array}$ & $\begin{array}{l}61(35-76) \\
71(56-84) \\
57(26-80) \\
54(39-70) \\
35(18-51) \\
55(33-84)\end{array}$ & $\begin{array}{l}\text { Parapneumonic effusion } \\
\text { Bacterial empyema } \\
\text { Tuberculous pleurisy* } \\
\text { Rheumatoid arthritis } \dagger \\
\text { Systemic lupus erythematosus } \dagger \\
\text { Pleural effusions caused by cancer: } 26 \text { patients with } \\
\text { pulmonary carcinoma and } 4 \text { with malignant } \\
\text { mesothelioma; } 12 \text { patients with extrapulmonary } \\
\text { cancer; } 9 \text { patients with cancer and evidence of liver } \\
\text { metastases }\end{array}$ \\
\hline 4 & $0: 4$ & $77(56-86)$ & $\begin{array}{l}\text { Transudative pleural effusions caused by congestive } \\
\text { heart failure }\end{array}$ \\
\hline 19 & $13: 6$ & $61(32-83)$ & $\begin{array}{l}\text { Non-specific pleural effusions } \\
\text { Diagnosis was made after the above mentioned types of } \\
\text { pleurisy had been ruled out }\end{array}$ \\
\hline
\end{tabular}

*In seven patients the diagnosis was based on a positive culture of Mycobacterium tuberculosis or a pleural biopsy specimen compatible with active tuberculosis. In five patients the diagnosis was based on clinical findings and a favourable response to specific antituberculous treatment.

†Diagnosed according to criteria of the American Rheumatism Association.

Table 2 Median concentration of serum ferritin for each group of patients

\begin{tabular}{|c|c|c|c|c|}
\hline \multirow[t]{2}{*}{ Diagnosis } & \multicolumn{2}{|l|}{ Men } & \multicolumn{2}{|l|}{ Women } \\
\hline & $\begin{array}{l}\text { Serum ferritin concentration } \\
(\mu g / l) \text { Median (range) }\end{array}$ & No of patients & $\begin{array}{l}\text { Serum ferritin concentration } \\
(\mu g / l) \text { Median (range) }\end{array}$ & No of patients \\
\hline Inflammatory pleural effusion* & $210(50-1580)$ & $\begin{array}{r}31 \\
5\end{array}$ & $138(51-430)$ & $\frac{7}{-}$ \\
\hline Congestive heart failure & $209(30-1700)$ & - & $\overline{102}(50-840)$ & 4 \\
\hline $\begin{array}{l}\text { Cancer } \\
\text { ( } 3 \text { patients with liver metastases } \\
\text { were excluded) }\end{array}$ & $230(78-560)$ & 12 & $165(18-290)$ & 8 \\
\hline
\end{tabular}

*Tuberculosis, pneumonia, rheumatoid arthritis, systemic lupus erythematosus, and non-specific pleural effusions.

Pleural fluid was analysed cytologically and stained and cultured for the presence of bacteria, including $M$ tuberculosis. For measurement of ferritin concentration blood and pleural fluid were collected on the same day. After centrifugation the serum and pleural fluid were stored at $-20^{\circ} \mathrm{C}$ until assayed. Ferritin was measured by an immunoradiometric method (Ramco Laboratories Inc, Houston, Texas) ${ }^{1011}$ with human spleen ferritin as the standard. Recovery of spleen ferritin added to pleural fluid samples was $93-118 \%$, mean $108 \%$ $(n=6)$. Dilution curves of pleural fluid samples paralleled those of the standards, which indicates immunological identity of pleural fluid and spleen ferritin in the assay. The reference values for the concentration of ferritin in serum were $20-120 \mu \mathrm{g} / \mathrm{l}$ for women and 40-240 $\mu \mathrm{g} / 1$ for men. Because of differences between men's and women's concentrations of ferritin, the results are presented separately.

Immunocytochemical visualisation of ferritin in pleural fluid cells was performed using an immunoperoxidase technique. ${ }^{12}$ Cytocentrifuged pleural fluid cells were fixed in formol-calcium (Baker's solution). The cells were then washed, and endogenous peroxidase in the cells was inactivated by treatment with methanol and hydrogen peroxide.
The cells were washed again in phosphate buffered saline and then treated for $30 \mathrm{~min}$ in succession with rabbit antihuman ferritin (dilution $1 / 200$, Dakopatts, Copenhagen, Denmark), sheep antirabbit gammaglobulin (1/20), and rabbit antihorseradish peroxidase (1/150) Between each application of antiserum the cells were washed twice for 5 min with phosphate buffered saline. After incubation with horseradish peroxidase the enzyme was identified by the method of Graham and Karnovsky. ${ }^{13}$ Control staining was performed either with an antiserum absorbed with ferritin (Sigma Chemical Company, USA) or by omitting the primary antiserum.

Statistical significance was tested by Wilcoxon's rank test and linear regression analysis.

\section{Results}

Table 2 gives the median concentration of ferritin in serum for each group of patients. No significant differences were found between the values.

Figs. 1 and 2 show the concentrations of ferritin in the pleural fluid of patients with non-malignant diseases and of patients with cancer, respectively. Median values are given in Table 3. Significant differences between the median values of ferritin in the 
Table 3 Median concentration of ferritin in pleural fuid for each group of patients

\begin{tabular}{|c|c|c|c|c|}
\hline \multirow[t]{2}{*}{ Diagnosis } & \multicolumn{2}{|l|}{ Men } & \multicolumn{2}{|l|}{ Women } \\
\hline & $\begin{array}{l}\text { Pleural fuid ferritin } \\
\text { concentration }\left(\mu g^{\prime l}\right) \text { Median }\end{array}$ & No of patients & $\begin{array}{l}\text { Pleural fuid ferritin } \\
\text { concentration }(\mu \mathrm{g} / \mathrm{l}) \text { Median }\end{array}$ & No of patients \\
\hline $\begin{array}{l}\text { Pneumonia } \\
\text { Empyema } \\
\text { Tuberculosis } \\
\text { Non-specific pleural effusions } \\
\text { Rheumatoid arthritis } \\
\text { Systemic lupus erythematosus } \\
\text { Congestive heart failure } \\
\text { Pulmonary carcinoma } \\
\text { Extrapulmonary carcinoma } \\
\text { Cancer and evidence of liver } \\
\text { metastases }\end{array}$ & $\begin{array}{r}915 \\
7000 \\
1685 \\
780 \\
5390 \\
970 \\
- \\
1765 \\
3900 \\
7900\end{array}$ & $\begin{array}{r}5 \\
5 \\
10 \\
13 \\
8 \\
2 \\
22 \\
2 \\
5\end{array}$ & $\begin{array}{r}- \\
-870 \\
350 \\
1800 \\
1450 \\
1265 \\
1200 \\
585 \\
1895\end{array}$ & $\begin{array}{r}- \\
2 \\
6 \\
1 \\
1 \\
4 \\
8 \\
10 \\
4\end{array}$ \\
\hline
\end{tabular}

Fig. 1 Concentrations of ferritin in pleural fuid. Values for men (O) and women (O) are shown separately. Pneum = pneumonia; $T b c=$ tuberculosis; $R A=$ rheumatoid arthritis; $S L E=$ systemic lupus erythematosus; $\mathrm{CHF}=$ congestive heart failure. 

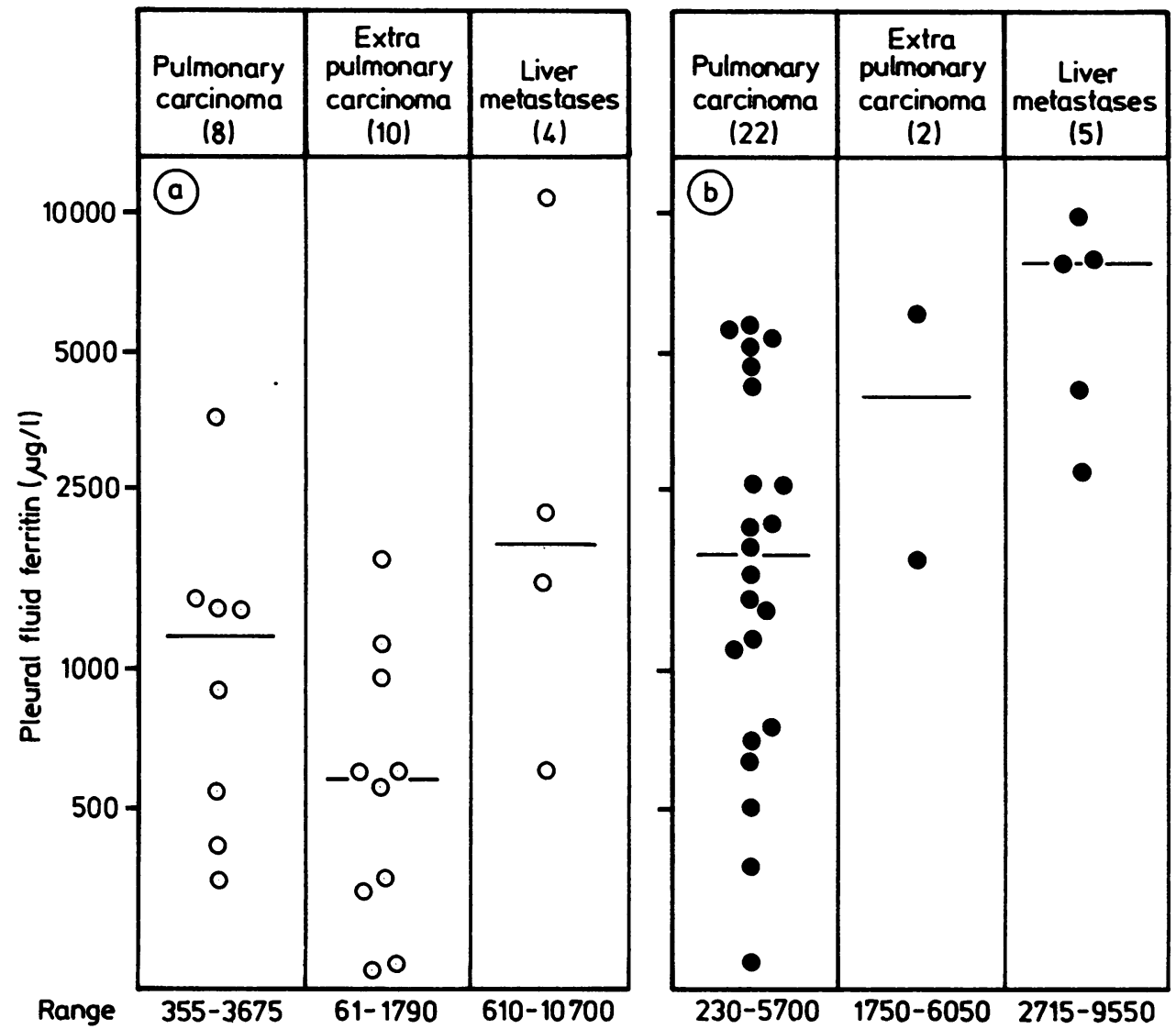

Fig. 2 Concentration of ferritin in the pleural fuid of men (O) and women (O) with cancer. The median concentration is indicated by the bar and the range is seen below the figure.

pleural fluid were as follows: men with rheumatoid arthritis had significantly higher concentrations than men with non-specific pleural effusions $(p<0.05)$ or pneumonia $(\mathrm{p}<0.01)$; men with empyema had significantly higher concentrations than men with non-specific pleural effusions $(p<0.05)$; and men with cancer and signs of liver metastases had significantly higher concentrations than men with non-specific pleural effusions $(p<0.05)$, tuberculosis $(p<0.001)$, pneumonia $(p<0.05)$, or cancer of the lung without liver metastases $(\mathrm{p}<0.05)$.

Table 4 shows the clinical data, serum and pleural fluid ferritin concentrations, and other indices of inflammatory activity in the pleural fluid of nine patients with rheumatoid arthritis. High pleural fluid ferritin concentrations are associated with increased lactate dehydrogenase values and low concentrations of complement components in the pleural fluid.
Table 5 shows the relation between the ferritin concentrations in pleural fluid and other laboratory indices of pleural inflammation in men with nonmalignant inflammatory pleural effusions - that is, patients with tuberculosis, pneumonia, rheumatoid arthritis, systemic lupus erythematosus, and nonspecific pleural effusions. There was a highly significant correlation $(p<0.001)$ between the concentration of ferritin and lactate dehydrogenase activity and an inverse correlation between the concentrations of ferritin and complement component C3.

Immunocytochemical staining of ferritin in pleural fluid cells showed strong positive staining in vacuolated macrophages (Fig. 3a), whereas mesothelial cells, granulocytes, and lymphocytes were not stained for ferritin. Fig. 3b shows the absence of specific staining in a cell preparation in which primary rabbit antiferritin antiserum was replaced with an antiserum absorbed with purified 
Table 4 Clinical data for nine patients with seropositive rheumatoid arthritis and pleural effusion

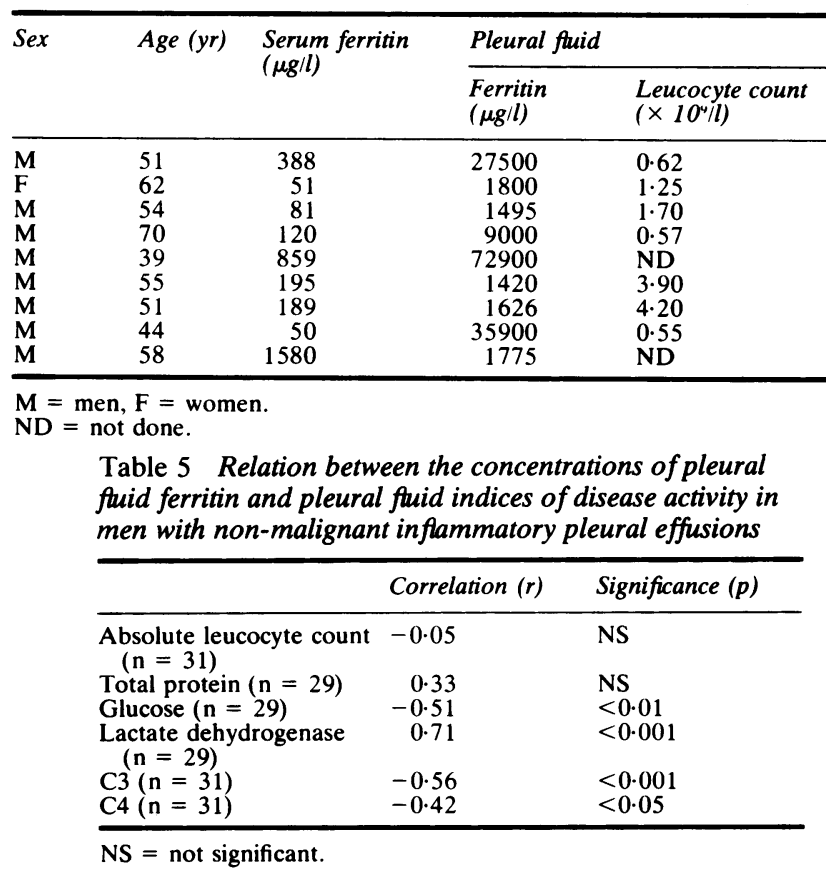

human ferritin.

\section{Discussion}

Determination of biochemical, immunological, and cellular variables in pleural fluid has helped in both the diagnosis and understanding of the pathogenetic events of exudative pleural effusions. ${ }^{14}$ In the present study the concentration of ferritin was higher in pleural fluid than in serum for all the groups of patients, including patients with transudative effusions caused by congestive heart failure. The concentrations of ferritin in the pleural fluid were four to one hundred times higher than values in the blood, the greatest difference being for patients with empyema, cancer, or rheumatoid arthritis. Although there are reports of increased serum ferritin concentrations in patients with some types of cancer, ${ }^{14}$ we did not find significantly higher values in patients with cancer of the lung when compared with patients who had inflammatory lung diseases. Measurement of ferritin concentration in pleural fluid, however, gave some hint of the diagnosis of malignant pleural effusion. Patients with cancer but without liver metastases had high concentrations of ferritin (above $1000 \mu \mathrm{g} / \mathrm{l}$ ) in pleural fluid; such high values were found for two thirds of the men and one third of the women. Furthermore, patients with cancer and with liver metastases had even higher ferritin

concentrations in pleural fluid.

The turnover and metabolism of ferritin in effusions is poorly understood. A delayed diffusion of locally produced, high molecular weight ferritin from pleural fluid into the circulation could account for the high ferritin concentrations. In acute infections and inflammatory conditions the redistribution of iron from plasma and red blood cell compartments may result in an increased synthesis of ferritin by the stimulated reticuloendothelial cells. In addition, ferritin may function as an acute phase reactant that mirrors disease activity independently of the metabolism of iron..$^{515}$ The mononuclear phagocytes of pleural fluid may have reticuloendothelial system activity within the pleural cavity aside from the possible reticuloendothelial like function of the pleural membrane. Of all blood cells, monocytes have the highest concentration of ferritin ${ }^{16}$; macrophages were the only cells in pleural fluid in which we detected ferritin immunocytochemically.

Human leucocytes contain different ratios of isoferritins. ${ }^{17}$ Because our assay measures only the spleen type ferritin, total pleural fluid ferritin concentrations have probably been underestimated.

In patients with cancer and liver metastases both the release of liver cell ferritin and the possibly reduced liver parenchymal cell clearance of ferritin may be responsible for the increased ferritin concentrations in body fluids. ' Besides local tissue necrosis, the production of isoferritins by malignant cells may increase the ferritin concentration in pleural fluid.' Iron released into the pleural cavity even during minor bleeding may also stimulate the local synthesis of ferritin. ${ }^{18}$ Phagocytic events close to the tumour may stimulate the local release of ferritin from mononuclear phagocytes, which contain and synthesise it. It is even possible that ferritin released from liver cells due to liver cell damage ultimately reaches the pleural cavity. Fluid passes from the peritoneal to the pleural space by means of the abundant lymphatics in the diaphragm. Observations of the flow routes of particles and proteins 


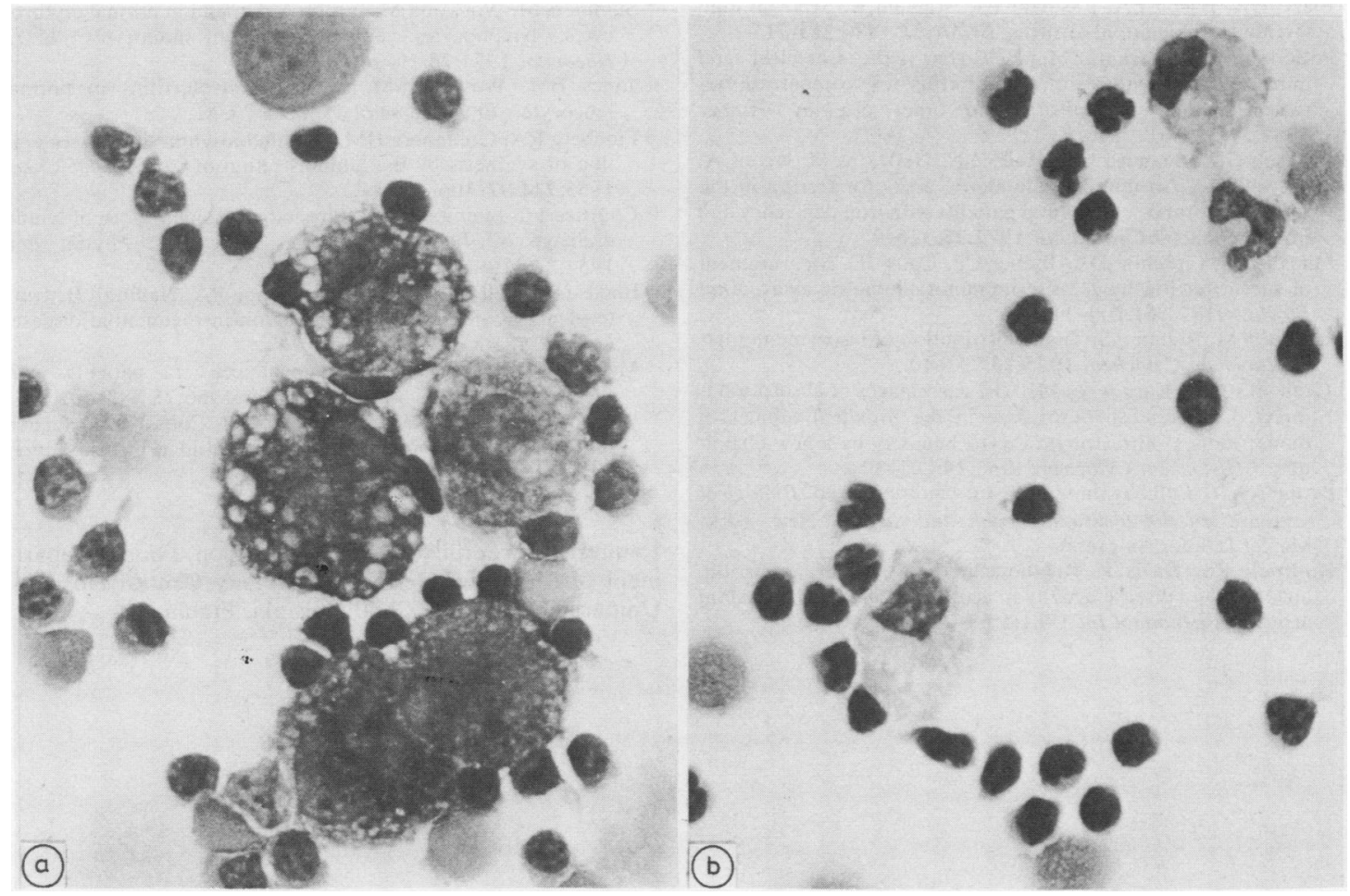

Fig. 3 Specific immunoperoxidase staining of ferritin in pleural ftuid macrophages (a) and absence of staining in control smears (b).

have suggested that the diaphragmatic lymphatic system plays the most important part in the absorption of peritoneal accumulations of fluid. ${ }^{19}$

According to the hypothesis presented by Blake et $a l$, free iron and ferritin are implicated in the inflammation of joints in rheumatoid arthritis. ${ }^{20}$ High concentrations of ferritin and ferric iron have been found in the synovial fluid of patients with rheumatoid arthritis. ${ }^{5}$ The phagocytic lining cells of the synovial membrane have many of the features of a reticuloendothelial organ..$^{21}$ In rheumatoid arthritis many of the biochemical changes noted in the synovial fluid correspond with those seen in the pleural fluid-for example, decreased concentrations of glucose and complement components (C3 and $\mathrm{C4}$ ) and increased concentrations of protein and lactate dehydrogenase activity." In rheumatic exudates the increased concentration of proteins such as lysozyme, fibronectin, and ferritin-all substances produced by activated mononuclear phagocytes-may reflect saturation and defective function of the reticuloendothelial system in rheumatoid arthritis. ${ }^{22}$ In fact, the suggestion of Blake $e t a^{20}$ that in men with rheumatoid arthritis the greater iron stores are likely to cause severe complications and maintain the local inflammatory process agrees well with the known fact that rheumatoid pleural effusion is seen mainly in men.

This study was supported by grants from the Sigrid Jusélius Foundation and Finska Läkaresällskapet Helsinki, Finland.

\section{References}

' Worwood M. Ferritin in human tissues and serum. Clin Haematol 1982;11:275-307.

${ }^{2}$ Lipschitz DA, Cook JD, Finch CA. A clinical evaluation of serum ferritin as an index of iron stores. $N$ Engl $J$ Med 1975;290: 1213-6.

${ }^{3}$ Prieto J, Barry M, Sherlock S. Serum ferritin in patients with iron overload and with acute and chronic liver diseases. Gastroenterology 1975;68:525-33.

4 Roeser HP. Iron metabolism in inflammation and malignant disease. In: Jacobs A, Worwood M, eds. Iron in biochemistry and medicine. London: Academic Press, 1980:605-40.

${ }^{5}$ Elin RJ, Wolf SM, Finch CA. Effect of induced fever on serum iron and ferritin concentrations in man. Blood 1977;49:14753.

${ }^{6} \mathrm{Konijn}$ AM, Hershko C. Ferritin synthesis in inflammation. I. Pathogenesis of impaired iron release. $\mathrm{Br} \mathrm{J}$ Haematol 1977;37:7-16.

' Birgegård G, Hallgren R, Killander A, Stromberg A, Venge P, Wide $\mathbf{L}$. Serum ferritin during infection. A longitudinal study. Scand J Haematol 1978;21:333-40. 
${ }^{*}$ Blake DR, Bacon PA, Eastham EJ, Brigham K. Synovial fluid ferritin in rheumatoid arthritis. Br Med J 1980;281:715-6.

${ }^{4}$ Pettersson T, Klockars M, Hellström P-E. Chemical and immunological features of pleural effusions: comparison between rheumatoid arthritis and other diseases. Thorax 1982;37:354-61.

10 Addison GM, Beamish MR, Hales CN, Hodgkins M, Jacobs A, Llewellin P. An immunoradiometric assay for ferritin in the serum of normal subjects and patients with iron deficiency and iron overload. J Clin Pathol 1972;25:326-9.

"Miles LEM, Lipschitz DA, Bieber CP, Cook JD. Measurement of serum ferritin by a 2-site immunoradiometric assay. Anal Biochem 1974;61:209-24.

${ }^{12}$ Klockars M, Reitamo S. Tissue distribution of lysozyme in man. J Histochem Cytochem 1975; 23:932-40.

${ }^{13}$ Graham RC Jr, Karnovsky MJ. The early stages of absorption in injected horseradish peroxidase in the proximal tubules of mouse kidney: ultrastructural cytochemistry by a new technique. J Histochem Cytochem 1966;14:291-302.

${ }^{14}$ Pettersson T. Cellular immunity. In: Chrétien J, ed. Biological responses of the pleura in health and disease. New York: Marcel Dekker (in press).

${ }^{15}$ Rothwell RS, Davis P. Relationship between serum ferritin, anaemia, and disease activity in acute and chronic rheumatoid arthritis. Rheumatol Int 1981;1:65-7.
${ }^{10}$ Summers M, Worwood M, Jacobs A. Ferritin in normal erythrocytes, lymphocytes, polymorphs and monocytes. $\mathrm{Br} J$ Haematol 1974;28:19-26.

17 Jones BM, Worwood $\mathbf{M}$, Jacobs $\mathbf{A}$. Isoferritins in normal leucocytes. Br J Haematol 1983;55:73-81.

${ }^{18}$ Fineberg RA, Greenberg DM. Ferritin biosynthesis. II Acceleration of synthesis by the administration of iron. J Biol Chem 1955;214:97-106.

${ }^{19}$ Courtice FC, Simmonds WJ. Physiological significance of lymph drainage of the serous cavities and lungs. Physiol Rev 1954;34:419-48.

${ }^{20}$ Blake DR, Hall ND, Bacon PA, Dieppe PA, Halliwell B, Gutteridge JMC. The importance of iron in rheumatoid disease. Lancet 1981;ii:1142-4.

${ }^{21}$ Muirden KD. Ferritin in synovial cells in patients with rheumatoid arthritis. Ann Rheum Dis 1966;25:387-401.

${ }^{22}$ Williams BD, Pussell BA, Lockwood CM, Cotton C. Defective reticuloendothelial function in rheumatoid arthritis. Lancet 1979;i:1311-4.

Requests for reprints to: Dr T Pettersson, Fourth Department of Medicine, Helsinki University Central Hospital, Unionsgatan 38, SF-00170 Helsinki, Finland. 